\title{
Derivative Spectrophotometric and HPLC Validated Methods for Simultaneous Determination of Metformin and Glibenclamide in Combined Dosage Form
}

\author{
NABIL A.F. ALHEMIARY1,2* \\ ${ }^{1}$ Department of Chemistry , College of Science \& Arts - Sharurah, \\ Najran University, Sharurah, Saudi Arabia. \\ ${ }^{2}$ Department of Chemistry, College of Science, University of IBB, P. O. Box 70270, Ibb, Yemen. \\ ${ }^{*}$ Corresponding author E-mail: dralhemiary@gmail.com \\ http://dx.doi.org/10.13005/ojc/300408
}

(Received: September 16, 2014; Accepted: November 03, 2014)

\begin{abstract}
The aim of the present Study was to develop a simple and rapid method for determination of metformin (MET) and glibenclamide (GLB) ) in Pharmaceutical dosage form. A high-performance liquid chromatographic, fist and second derivative spectrophotometric methods used for the simultaneous determination of MET and GLB. The first derivative amplitudes at $236 \mathrm{~nm}$ and 275.7 $\mathrm{nm}$ were selected for the assay of MET and GLB, respectively. Calibration curves were established at $5-120 \mu \mathrm{g} / \mathrm{ml}^{-1}$ for and $1-20 \mu \mathrm{g} / \mathrm{ml}^{-1}$, with limits of detection of $0.21 \mu \mathrm{g} / \mathrm{ml}^{-1}$ and $0.29 \mu \mathrm{g} / \mathrm{ml}^{-1}$ and limits of quantification of $0.64 \mu \mathrm{g} / \mathrm{ml}^{-1}$ and $0.89 \mu \mathrm{g} / \mathrm{mL}^{-1}$ for MET and GLB, respectively. The second derivative amplitudes at $244.6 \mathrm{~nm}$ and $229 \mathrm{~nm}$ were selected for the assay of MET and GLB, respectively. Calibration curves were established at $5-120 \mu \mathrm{g} / \mathrm{ml}^{-1}$ for and $1-20 \mu \mathrm{g} / \mathrm{ml}^{-1}$, with limits of detection of $0.46 \mu \mathrm{g} / \mathrm{ml}^{-1}$ and $0.30 \mu \mathrm{g} / \mathrm{ml}^{-1}$ and limits of quantification of $0.1 .41 \mu \mathrm{g} / \mathrm{ml}^{-1}$ and $0.91 \mu \mathrm{g} /$ $\mathrm{ml}^{-1}$ for MET and GLB, respectively. In the HPLC method separation was performed by using C18 reversed phase column and a mobile phase of acetonitrile: $0.05 \mathrm{M} \mathrm{KH}_{2} \mathrm{PO}_{4}(60: 40 \mathrm{v} / \mathrm{v})$ adjusted by phosphoric acid to $\mathrm{pH} 3$, at flow rate of $1 \mathrm{ml} / \mathrm{min}$ and the detection wavelength were $210 \mathrm{~nm}$ and $238 \mathrm{~nm}$, the retention time was found to be 3.145 and $7.792 \mathrm{~min}$, linearity over the concentration ranges of $5-75 \mu \mathrm{m} / \mathrm{ml}^{-1}$ and $2-45 \mu \mathrm{g} / \mathrm{ml}^{-1}$, with limits of detection of $0.64 \mu \mathrm{m} / \mathrm{l}^{-1}$ and $0.02 \mu \mathrm{g} / \mathrm{ml}^{-1}$ and limits of quantification of $1.95 \mu \mathrm{g} / \mathrm{l}^{-1}$ and $0.07 \mu \mathrm{g} / \mathrm{ml}^{-1}$ for MET and GLB, respectively. The methods were also applied for the determination of MET and GLB in the presence of their degradation products formed under variety of stress conditions. Proposed methods were validated for precision, accuracy, linearity range, robustness and ruggedness.
\end{abstract}

Key words: Simultaneous, Determination, Metformin, Glibenclamide, Derivative spectrophotometric, HPLC.

\section{INTRODUCTION}

Glibenclamide(GLB),5-chloro-N-[2$4[[[($ cyclohexylamino) carbonyl]-amino] sulphonyl]- phenyl]ethyl]-2-methoxy benzamide is a potent, second generation oral sulfonylurea antidiabetic agent widely used to lower blood glucose levels in patients with type 2 diabetes mellitus (Fig.1). It acts 
mainly by inhibiting ATP-sensitive potassium channels in pancreatic beta cells. This inhibition causes cell membrane depolarization, which cause voltage dependent calcium channels to open, which causes an increase in intracellular calcium in the beta cell, which stimulates insulin release. The literature survey reveals that few methods are reported for estimation of GLB ${ }^{1-6}$.

Metformin hydrochloride (MET) chemically, N,N-dimethyl-imidodicarbonimidi cdiamide hydrochloride is an antidiabetic agent from the biguanide class used in the management of type 2 diabetes (Fig.1). It does not cause insulin release from the pancreas and does not cause hypoglycemia, even in large dose. It decrease hepatic glucose production, decrease intestinal absorption of glucose and improves insulin sensitivity by increasing peripheral glucose uptake and utilization. Its predominant effect is to decrease fasting plasma glucose. Some methods have been reported in the literature for the estimation of MET in the presence of other drugs in formulations ${ }^{7-14}$. This combination can be achieved by taking each of the drugs separately or alternatively fixed formulations have been developed. Combinations of MET and GLB are available commercially as single tablets. Only few methods are available for the simultaneous estimation of MET and GLB ${ }^{15-22}$.

The objective of this study was to investigate the utility of derivative spectrophotometry, multivariate methods in addition to a fast and sensitive HPLC technique in the assay of GLB and MET in pharmaceutical preparation without the necessity of sample pre-treatment. The proposed methods were optimized and validated for this purpose. According to the ICH description, the developed methods were accurate and precise ${ }^{23}$.

\section{EXPERIMENTAL}

\section{Drug Substances and Dosage Form}

1,1-Dimethylbiguanid Hydrochlorid 97\% (Metformin, MET) and Glybenclamide 99\% pure substances, were kindly supplied by SPIMACO, AlQassim, Saudi Arabia. Diamet Tablets labeled to contain $500 \mathrm{mg} \mathrm{MET}$ and $5 \mathrm{mg}$ GLB (obtained from the Saudi Pharmaceutical Industries Medical Appliance (SPIMACO), Al-Qassim, Saudi.

\section{Chemicals}

Acetonitrile (Fisher Scientific, UK). Potassium dihydrogen phosphate $\left(\mathrm{KH}_{2} \mathrm{PO}_{4}\right)$ (SigmaAldrich Chemie, Germany). Orthophosphoric acid $\left(\mathrm{H}_{3} \mathrm{PO}_{4}\right)$ (Sigma-Aldrich Chemie, Germany). Methanol (Sigma-Aldrich Chemie, Germany). Acetonitrile is HPLC grade and all other chemicals are analytical reagent grade.

\section{Instrumentation \\ UV-Vis spectrophotometric}

A GENESYS 10S UV-Vis double beam spectrophotometer (Thermo Spectronic, USA) with a fixed slit width $(1.8 \mathrm{~nm})$ connected to an IBM computer loaded with Thermo Spectronic VISION Lite version 4 software and $1 \mathrm{~cm}$ quartz cell were used for the registration and treatment of absorption spectra. For all solutions, zero-order spectra were recorded over the range from 200.0 to $350.0 \mathrm{~nm}$ against a blank at intelliscan mode to enhance the signal to-noise ratio of absorbance peaks without extended scan duration with a $\lambda=5 \mathrm{~nm}$.

\section{High performance liquid chromatogram (HPLC)}

Agilent 1200 series isocratic quaternary pump HPLC instrument connected to 1200 multiple wavelength UV detector. Separation was performed by using $\mathrm{C} 18$ reversed phase column. Chromatographic peaks were electronically integrated and recorded using Chemstation software (Germany).

\section{Preparation of Standard Solutions and Calibration} Derivative spectrophotometry method

Accurately weighed $10 \mathrm{mg}$ of MET was taken and transferred to a $10 \mathrm{ml}$ volumetric flask, dissolved in methanol and diluted up to mark to obtain stock solution of $1000 \mu \mathrm{g} / \mathrm{ml}$. From this solution, $0.5 \mathrm{ml}$ was diluted to $10 \mathrm{ml}$ to get $50 \mu \mathrm{g} / \mathrm{ml}$ standard MET solutions. Accurately about $1 \mathrm{mg}$ of GLB was weighed and transferred to a $10 \mathrm{ml}$ amber colored volumetric flask and dissolved in methanol and volume was made up to mark to get stock solution of $100 \mu \mathrm{g} / \mathrm{ml}$. From this solution, $0.2 \mathrm{ml}$ was further diluted to $10 \mathrm{ml}$ to get $20 \mu \mathrm{g} / \mathrm{ml}$ standard GBL solutions. Aliquots of 0.1 to $2.4 \mathrm{ml}$ MET and 0.05 to $1 \mathrm{ml} \mathrm{GLB}$ were transferred into $10 \mathrm{ml}$ volumetric flasks to reach the concentration ranges of $5-120 \mu \mathrm{g} / \mathrm{ml}$ for MET and $1-20 \mu \mathrm{g} / \mathrm{ml}$ for GLB. 


\section{HPLC method}

MET and GLB stock solutions in methanol were prepared by dissolving $10 \mathrm{mg}$ of both drugs in $10 \mathrm{ml}$ volumetric flasks $(100 \mu \mathrm{g} / \mathrm{ml})$. Series of working solutions of MET and GLB were prepared by the appropriate dilution of the stock solutions with same solvent to reach the concentration ranges of $5-75 \mu \mathrm{g} / \mathrm{ml}$ for MET and 2-45 $\mathrm{gg} / \mathrm{ml}$ for GLB. Triplicate $20 \mu \mathrm{l}$ injections were made for each concentration using the following chromatographic conditions: Mobile phase consisting of

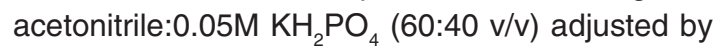
phosphoric acid to $\mathrm{pH}$ 3. Detector wavelength: 210 $\mathrm{nm}$ for MET and $238 \mathrm{~nm}$ for GLB, flow rate: $1 \mathrm{ml} / \mathrm{min}$ at ambient temperature. Peak area of each concentration was plotted against the corresponding concentration for the construction of calibration graph.

\section{Sample Preparation}

Twenty tablets were weighed and finely powdered. An amount of the tablet powder equivalent to $500 \mathrm{mg}$ of MET and $5 \mathrm{mg}$ of GLB were weighed and finely powdered, a quantity of $10 \mathrm{mg}$ of MET and $0.1 \mathrm{mg}$ of GLB was weighed and transferred to $100 \mathrm{ml}$ volumetric flask containing about $50 \mathrm{ml}$ methanol. The solution was then solicited for 10 minutes and finally volume was made up to the $100 \mathrm{ml}$ mark with diluent. Solution was filtered through Whatman grade No.42 filter paper. The final concentration of MET $100 \mu \mathrm{g} / \mathrm{ml}$ and GLB $1 \mu \mathrm{g} / \mathrm{ml}$ and this solution was used for the estimation.

\section{Procedure for forced degradation study:}

Degradation studies were performed in solutions containing drug at a concentration of $40 \mu \mathrm{g} /$ $\mathrm{ml}$ for MET and $20 \mu \mathrm{g} / \mathrm{ml}$ for GLB. Samples were withdrawn and subjected to HPLC analysis, after suitable dilution. The stress conditions were as follows:

Stress degradation by hydrolysis under acidic conditions

For acid degradation study $1 \mathrm{ml}$ of $0.1 \mathrm{M}$ $\mathrm{HCl}$ was added to final drug solution. And it was refluxed for $2 \mathrm{hr}$ at $80^{\circ} \mathrm{C}$. After $2 \mathrm{hr}$ this solution was injected in stabilized chromatographic condition.

\section{Stress degradation by hydrolysis under alkaline conditions}

For alkali degradation study $1 \mathrm{ml}$ of $0.1 \mathrm{M}$
$\mathrm{NaOH}$ was added to final drugsolution. And it was refluxed for $2 \mathrm{hr}$ at $80^{\circ} \mathrm{C}$. After $2 \mathrm{hr}$ this solution was injected in stabilized chromatographic condition.

\section{Oxidative degradation}

For oxidation study $1 \mathrm{ml}$ of $3 \% \mathrm{v} / \mathrm{v} \mathrm{H}_{2} \mathrm{O}_{2}$ was added to final drug solution. And it was refluxed for $2 \mathrm{hr}$ at $80^{\circ} \mathrm{C}$. After $2 \mathrm{hr}$ this solution was injected in stabilized chromatographic condition.

\section{Temperature stress studies}

For temperature stress studies final drug solution was refluxed for $2 \mathrm{hr}$ at $80^{\circ} \mathrm{C}$. And then after $2 \mathrm{hr}$ this solution was injected in stabilized chromatographic condition.

\section{RESULTS AND DISCUSSION}

\section{Absorption spectra}

The absorption spectra of MET and GLB and for their mixture were recorded. Fig. 2 shows the absorption spectrum of MET solution $(20 \mu \mathrm{g} / \mathrm{ml})$ with two maxima at wavelength $226 \mathrm{~nm}$ and $274 \mathrm{~nm}$, curve (b) show the absorption spectrum of GLB solution $(10 \mu \mathrm{g} / \mathrm{ml})$ with maximum wavelength of absorption at $212 \mathrm{~nm}$. The total spectrum of mixture of is shown in curve (c) with $\lambda_{\text {max }}(214 \mathrm{~nm})$ between the absorption maxima of the two components.

First and second derivative spectrophotometric methods

The first and second orders derivative spectra of MET and GLB and for their mixture are shown in Fig. 3 and Fig. 4 respectively. It is obvious that there is a large overlap of the spectra of MET and GLB therefore, their determination, using the zero order absorption measurements, when present in the same solution is very difficult when using traditional two wavelengths of maximal absorption or the tangential base-line approximation techniques. On the other hand, derivative spectrophotometric technique is of a particular utility in determining the concentration of single component in such mixtures, with a large spectral overlapping. For this reason, derivative spectrophotometric methods have been applied. Both first and second order modes were tested, the results obtained show that these techniques could successfully applied when the measurements are carried out under optimum selection of slit width, 
response time, and scan speed for the monochromator. These were done by measuring the magnitude of derivative at several slit widths and scan speed with different response times. A slit width of $2 \mathrm{~nm}$, a response time of 4 seconds and fast scan speed were found to be optimum.

Table 1: Analytical parameters for the determination of MET and GLB by the proposed methods

\begin{tabular}{|c|c|c|c|c|c|c|}
\hline \multirow[t]{3}{*}{ Parameter } & \multicolumn{3}{|c|}{ MET } & \multicolumn{3}{|c|}{ GBL } \\
\hline & \multicolumn{2}{|c|}{$\begin{array}{c}\text { Derivative } \\
\text { spectrophotometric } \\
\text { methods } \\
\end{array}$} & \multirow[t]{2}{*}{$\begin{array}{l}\text { HPLC } \\
\text { method }\end{array}$} & \multicolumn{2}{|c|}{$\begin{array}{c}\text { Derivative } \\
\text { spectrophotometric } \\
\text { methods } \\
\end{array}$} & \multirow[t]{2}{*}{$\begin{array}{l}\text { HPLC } \\
\text { method }\end{array}$} \\
\hline & ${ }^{1} \mathrm{D}$ & ${ }^{2} \mathrm{D}$ & & ${ }^{1} \mathrm{D}$ & ${ }^{2} \mathrm{D}$ & \\
\hline Wavelength (nm) & 236 & 244.6 & 207 & 275.7 & 229 & 238 \\
\hline Linearity range $(1 / 4 \mathrm{~g} / \mathrm{ml})$ & $5-120$ & $5-120$ & $5-75$ & $1-20$ & $1-20$ & $2-45$ \\
\hline Correlation coefficient $\left(r^{2}\right)$ & 0.9974 & 0.9986 & 0.9996 & 0.9984 & 0.9990 & 0.9995 \\
\hline Intercept (a) & 0.0645 & 0.0024 & 0.150 & 0.0036 & 0.0013 & 0.031 \\
\hline Slope (b) & 0.00048 & 0.00004 & 0.179 & 0.00045 & 0.00006 & 0.346 \\
\hline $\begin{array}{l}\text { Standard deviation of the } \\
\text { intercept (Sa) }\end{array}$ & 0.000236 & $2.28 \times 10^{-5}$ & 0.035 & $2.69 \times 10^{-5}$ & $9.07 \times 10^{-6}$ & 0.0025 \\
\hline $\begin{array}{l}\text { Standard deviation of the } \\
\text { slope }(\mathrm{Sb})\end{array}$ & 0.000293 & 0.00122 & 0.022 & 0.000383 & 0.000108 & 0.0065 \\
\hline Standard deviation (SD) & 0.0037 & 0.0002 & 1.081 & 0.0003 & 0.0001 & 1.4914 \\
\hline $\begin{array}{l}\text { Limit of detection } \operatorname{LOD}(\mu \mathrm{g} / \mathrm{ml}) \\
\text { Limit of quantification }\end{array}$ & 0.21 & 0.46 & 0.64 & 0.29 & 0.30 & 0.02 \\
\hline LQD $(\mu \mathrm{g} / \mathrm{ml})$ & 0.64 & 1.41 & 1.95 & 0.89 & 0.91 & 0.07 \\
\hline
\end{tabular}

Table 2: Recovery studies

\begin{tabular}{|c|c|c|c|c|c|}
\hline Compound & Method of analysis & Taken $(\mu \mathrm{g} / \mathrm{ml})$ & Mean $\pm \mathrm{SD}(\mu \mathrm{g} / \mathrm{ml})$ & \%RSD & \%Recovery $(n=3)$ \\
\hline \multirow[t]{9}{*}{ MET } & ${ }^{1} \mathrm{D}$ & 20 & $20.07 \pm 0.102$ & 0.05 & 100.35 \\
\hline & & 40 & $39.36 \pm 0.356$ & 0.90 & 98.40 \\
\hline & & 60 & $60.46 \pm 0.197$ & 0.32 & 100.8 \\
\hline & ${ }^{2} \mathrm{D}$ & 20 & $20.13 \pm .0 .167$ & 0.83 & 100.65 \\
\hline & & 40 & $40.53 \pm 0.501$ & 1.23 & 101.32 \\
\hline & & 60 & $60.34 \pm 0.098$ & 1.62 & 100.57 \\
\hline & HPLC & 20 & $20.06 \pm 0.173$ & 0.87 & 100.30 \\
\hline & & 40 & $40.04 \pm 0.112$ & 0.28 & 100.11 \\
\hline & & 60 & $59.76 \pm 0.531$ & 0.89 & 99.60 \\
\hline \multirow[t]{9}{*}{ GLB } & ${ }^{1} \mathrm{D}$ & 10 & $9.82 \pm 0.105$ & 1.07 & 98.20 \\
\hline & & 20 & $20.21 \pm 0.292$ & 1.44 & 101.05 \\
\hline & & 30 & $30.02 \pm 0.117$ & 0.39 & 100.07 \\
\hline & ${ }^{2} \mathrm{D}$ & 10 & $10.23 \pm 0.182$ & 1.77 & 102.3 \\
\hline & & 20 & $20.08 \pm 0.120$ & 0.59 & 100.4 \\
\hline & & 30 & $30.14 \pm 0.092$ & 0.31 & 100.47 \\
\hline & HPLC & 10 & $9.97 \pm 0.066$ & 0.67 & 99.7 \\
\hline & & 20 & $20.06 \pm 0.038$ & 0.19 & 100.3 \\
\hline & & 30 & $30.02 \pm 0.047$ & 0.16 & 100.07 \\
\hline
\end{tabular}


In the present work, graphically peak-tobase line technique was used to deal with derivatives spectra to carry out the measurements.In fact that all these techniques in the first and second derivative modes show good proportionality to MET and GLB concentrations in their mixtures.

Fig. 5 and Fig. 6 show sets of first order spectra of mixtures containing different amounts of each of MET and GLB in the presence of $(20 \mu \mathrm{g} / \mathrm{ml})$ of the other compound respectively.

The results in Fig. 5 indicate that when the concentration of GBL is kept constant and the concentration of MET varied, the peak areas at the intervals $(202-224 \mathrm{~nm})$ and $(224-262 \mathrm{~nm})$ were proportional to the concentration of MET. Moreover, the peak-to-base line (i.e. amplitude measured in millimeter) at (236nm) was found in proportion to the MET concentration. The same features were found when inspecting Fig. 6 for the determination of GLB, i.e. peak areas in the wavelengths intervals of $(225-254 \mathrm{~nm}),(254-294 \mathrm{~nm})$ and the peak amplitude measured at peak-to-baseline $(275.5 \mathrm{~nm})$ and at zero cross of MET $(223.9 \mathrm{~nm})$ were in proportion to the concentration of GLB (Table1).

Fig. 7 and Fig. 8 show further sets of second derivative of the same above mixtures. Applying the same mentioned techniques in measuring peak amplitudes (in millimeter) at peak-to-base line and at zero crossing point of the other compound, and peak areas at selected wavelengths intervals enable the measurement of MET and GLB respectively (Table 1).

\section{HPLC method}

To perform the simultaneous elution of MET and GLB peaks, different chromatographic conditions were optimized. The composition of the mobile phase was studied by trying acetonitrile and $0.05 \mathrm{M}$ of $\mathrm{KH}_{2} \mathrm{PO}_{4}$ in different ratios using gradient

Table 3: Assay of MET and GLB in tablets using the proposed methods

\begin{tabular}{|c|c|c|c|c|c|c|c|c|c|}
\hline $\begin{array}{l}\text { Pharmaceutical } \\
\text { preparation }\end{array}$ & $\begin{array}{l}\text { Method of } \\
\text { analysis }\end{array}$ & $\lambda(\mathrm{nm})$ & $\begin{array}{l}\text { Labeled } \\
\text { amount } \\
\text { mg/tablet }\end{array}$ & $\begin{array}{l}\text { Amout } \\
\text { found* } \\
\text { (in mg) }\end{array}$ & $\begin{array}{c}\text { \%Recovery } \\
\pm S D^{*}\end{array}$ & \%RSD & $\%$ Er & $\begin{array}{c}\mathrm{T}- \\
\text { test**}^{*}\end{array}$ & $\begin{array}{c}\mathrm{F} \\
\text { test**}^{*}\end{array}$ \\
\hline \multirow[t]{3}{*}{ Metformine } & ${ }^{1} \mathrm{D}$ & 236 & 500 & 500.65 & $100.13 \pm 1.01$ & 1.01 & 0.13 & 1.02 & 2.07 \\
\hline & ${ }^{2} \mathrm{D}$ & 244.6 & 500 & 503.95 & $100.79 \pm 1.39$ & 1.38 & 0.79 & 1.18 & 1.29 \\
\hline & HPLC & 207 & 500 & 500.85 & $100.17 \pm 0.16$ & 0.16 & 0.17 & 1.04 & 1.20 \\
\hline \multirow[t]{3}{*}{ Glibenclamide } & ${ }^{1} \mathrm{D}$ & 275.7 & 5 & 2.49 & $99.59 \pm 1.43$ & 1.44 & -0.42 & 1.43 & 3.10 \\
\hline & ${ }^{2} \mathrm{D}$ & 229 & 5 & 2.51 & $100.48 \pm 0.78$ & 0.78 & 0.48 & 0.92 & 1.61 \\
\hline & HPLC & 238 & 5 & 2.50 & $100.02 \pm 0.26$ & 0.26 & 0.02 & 0.51 & 1.97 \\
\hline
\end{tabular}

* Mean \% recovery \pm SD for five determinations.

$p=0.05 ; t=2.78 ; f=6.25$

Table 4: Results of forced degradation studies

\begin{tabular}{|c|c|c|c|c|c|}
\hline \multirow[t]{2}{*}{$\begin{array}{l}\text { Stress } \\
\text { condition }\end{array}$} & \multirow[t]{2}{*}{$\begin{array}{l}\text { Time } \\
\text { (hours) }\end{array}$} & \multicolumn{2}{|c|}{$\begin{array}{l}\text { \% Assay of active } \\
\text { substance }\end{array}$} & \multicolumn{2}{|c|}{$\begin{array}{c}\text { Mass balance ( } \% \text { assay }+\% \\
\text { degradation products }\end{array}$} \\
\hline & & MET & GLB & MET & GLB \\
\hline Acid hydrolysis $(0.1 \mathrm{M} \mathrm{HCl})$ & 24 & 82.6 & 98.56 & 101.8 & 98.56 \\
\hline Base hydrolysis $(0.1 \mathrm{NaOH})$ & 24 & 85.72 & 99.31 & 99.16 & 99.31 \\
\hline Oxidation $\left(3 \% \mathrm{H}_{2} \mathrm{O}_{2}\right)$ & 24 & 86.81 & 84.52 & 99.38 & 98.83 \\
\hline Thermal degradation $\left(80^{\circ} \mathrm{C}\right)$ & 24 & 84.2 & 87.66 & 98.74 & 99.61 \\
\hline
\end{tabular}


elution, The best peak shape and adequate separation of the two drugs was obtained by a final composition of acetonitrile- $\mathrm{KH}_{2} \mathrm{PO}_{4}(60: 40 \mathrm{v} / \mathrm{v})$ adjusted by phosphoric acid to $\mathrm{pH} 3$. Different flow rates $(0.5-1.2 \mathrm{ml} / \mathrm{min})$ were tested; good resolution was obtained using $1 \mathrm{ml} / \mathrm{min}$. Four wavelengths were tried $(210,230,238$ and $280 \mathrm{~nm})$; much sensitive detector response was obtained at 210 $\mathrm{nm}$ for MET and $283 \mathrm{~nm}$ for GLB. System suitability parameters were calculated and the retention times were found to be $3.415 \mathrm{~min}$ for MET and $7.792 \mathrm{~min}$ for GLB, Fig. 9. Resolution and selectivity factors for this system were found to be 2.22 and 2.51 for MET and GLB, respectively. Tailing and capacity factors were obtained as 1.21 and 0.91 for MET and 1.51 and 1.55 for GLB. Results obtained from system suitability tests are in agreement with the USP requirements.

\section{Method Validation}

The optimized first, second derivative spectrophotometric methods and HPLC were<smiles>COc1ccc(Cl)cc1C(=O)NCCc1ccc(S(=O)(=O)NC(N)=O)cc1</smiles>

(A)<smiles>CN(C)C(=N)NC(=N)N</smiles>

(B)

Fig.1: Chemical structure of Glibenclamide (A) and Metformin (B)

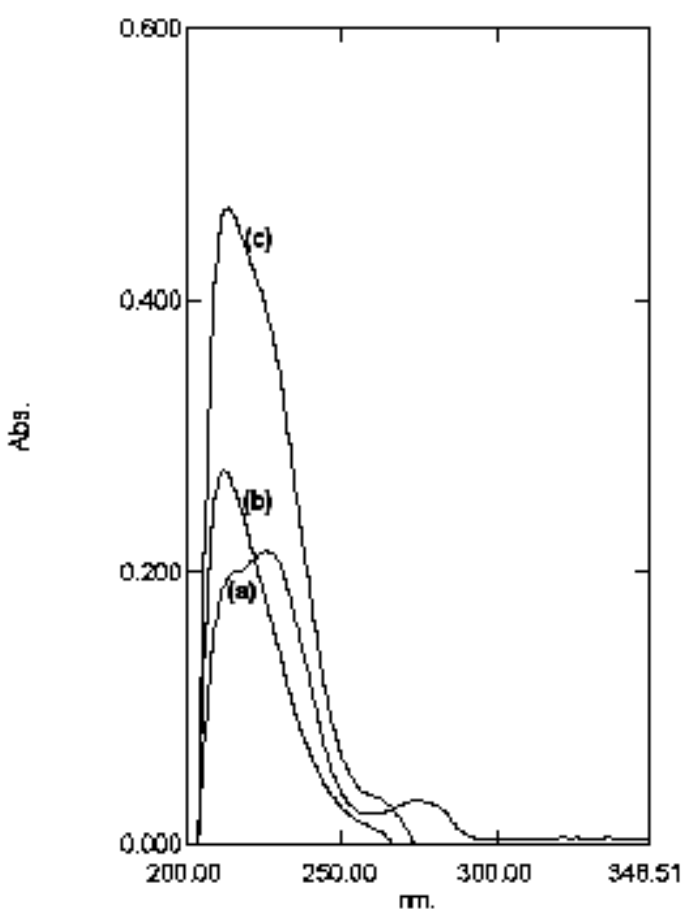

Fig. 2: Absorpstion spectra of (a) $20 \mu \mathrm{g} / \mathrm{ml}$ of MET, (b) $10 \mu \mathrm{g} / \mathrm{ml}^{-1}$ of GLB, (c) MET plus GLB

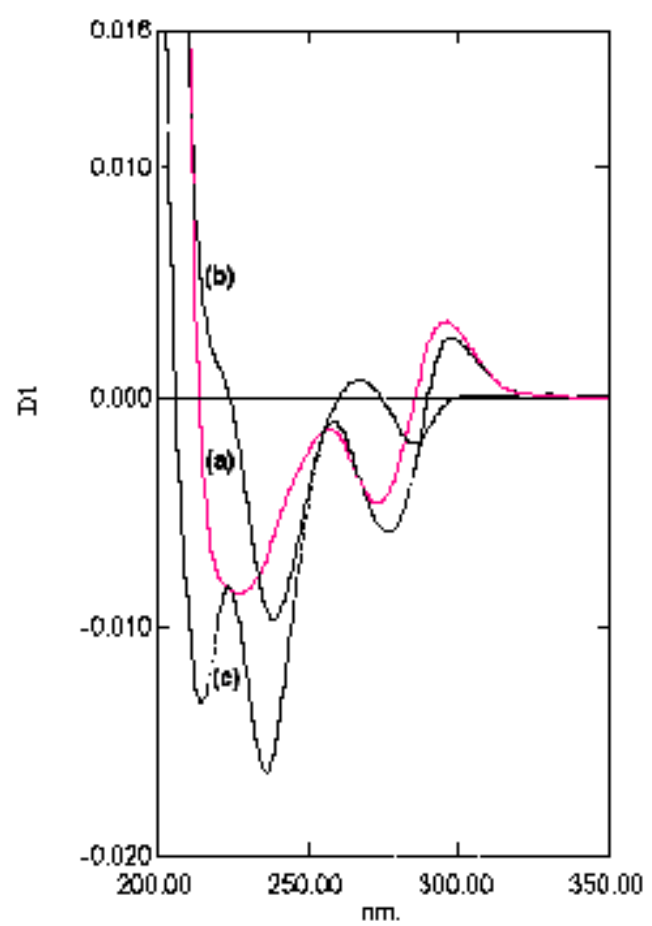

Fig. 3: First derivative spectra of : (a) $20 \mu \mathrm{g} \cdot \mathrm{ml}^{-1}$ of MET, (b) $20 \mu \mathrm{g} \cdot \mathrm{ml}^{-1}$ of GBL, (c) MET plus GLB 


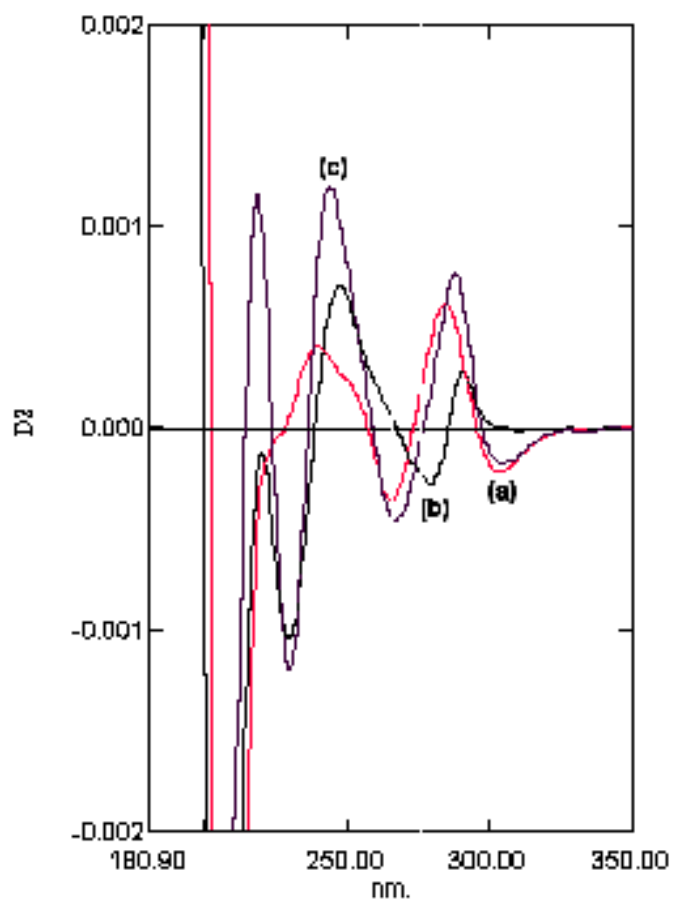

Fig.4: Second derivative spectra of : (a) $20 \mu \mathrm{g} \cdot \mathrm{ml}$ ${ }^{1}$ of MET, (b) $20 \mu \mathrm{g} \cdot \mathrm{ml}^{-1}$ of GLB, (c) MET plus GLB

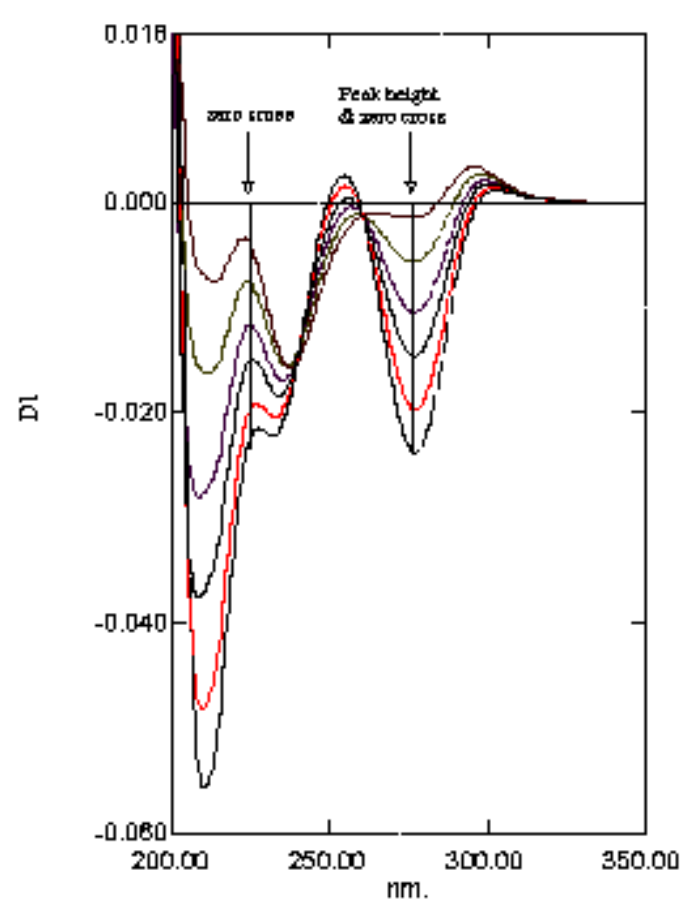

Fig. 6: First derivative spectra of mixtures containing $\left(2-20 \mu \mathrm{g} \cdot \mathrm{ml}^{-1}\right)$ GLB and $20 \mu \mathrm{g} \cdot \mathrm{ml}^{-1}$ of MET

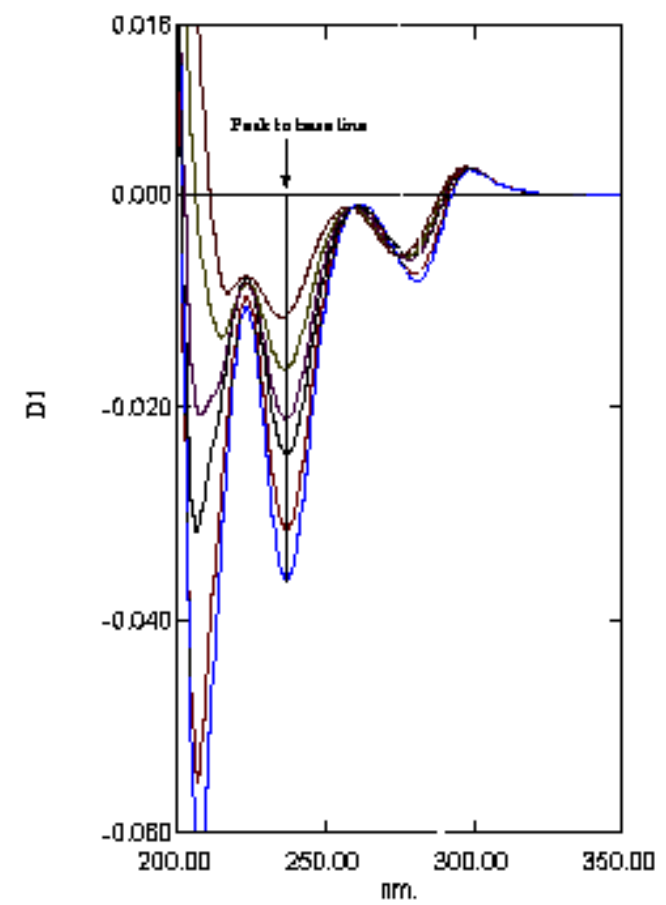

Fig.5: First derivative spectra of mixtures containing $\left(10-120 \mu \mathrm{g} \cdot \mathrm{ml}^{-1}\right)$ MET and $20 \mu \mathrm{g} \cdot \mathrm{ml}$ of GBL

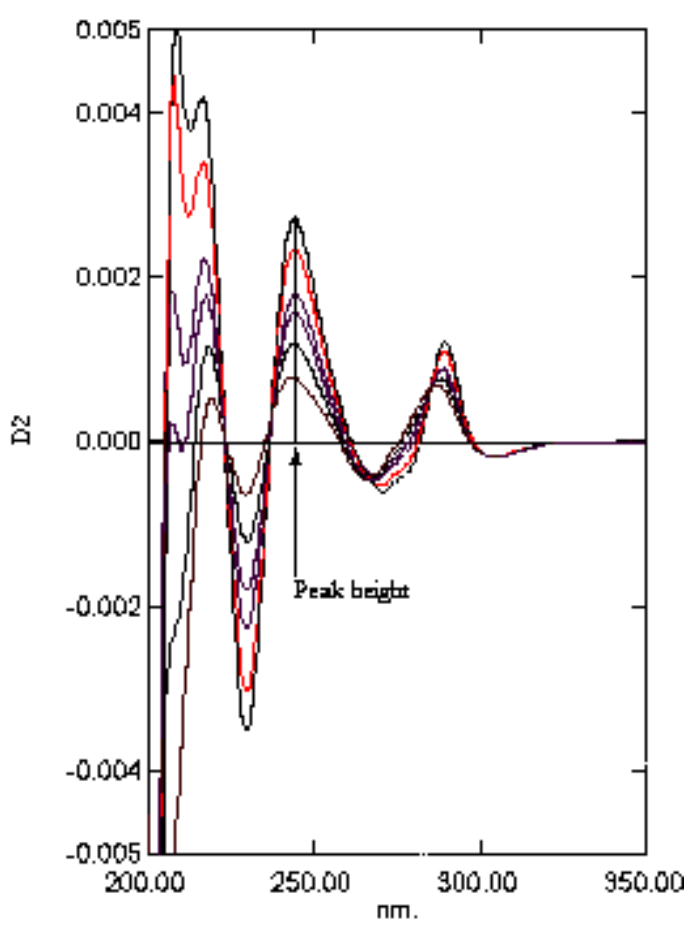

Fig.7: Second derivative spectra of mixtures containing $\left(10-120 \mu \mathrm{g} \cdot \mathrm{ml}^{-1}\right) \mathrm{MET}$ and $20 \mu \mathrm{g} \mathrm{ml}^{-1}$ of GLB 
completely validated according to the procedure described in $\mathrm{ICH}$ guidelines and United State Pharmacopoeia for validation of analytical methods.

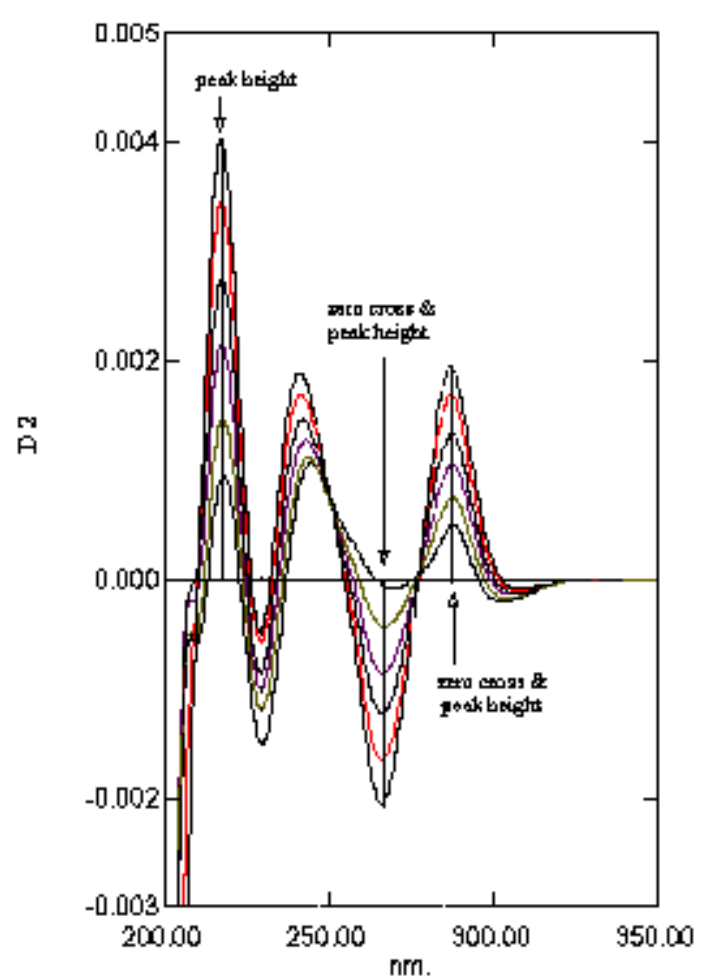

Fig.8: Second derivative spectra of mixtures containing $\left(2-20 \mu \mathrm{g} \cdot \mathrm{ml}^{-1}\right)$ GLB and $20 \mu \mathrm{g} \cdot \mathrm{ml}-1$ of MET
The performance parameters evaluated for the method were linearity, precision, accuracy, limits of detection and quantitation, and ruggedness.

\section{Linearity}

The calibration curve was tested with five concentrations of the standard solutions of MET and GLB, as $5-120 \mu \mathrm{g} / \mathrm{ml}$ and $1-20 \mu \mathrm{g} / \mathrm{ml}$ for First, Second derivative spectrophotometric methods and 5-75 $\mu \mathrm{g} / \mathrm{ml}$ and $2-45 \mu \mathrm{g} / \mathrm{ml}$ for HPLC method, respectively. The solutions were prepared in triplicate. The regression analysis data are represented in Table 1. The regression coefficients $\left(r^{2}\right)$ obtained was higher than 0.99 for MET and GLB, which attest the linearity of the method.

\section{Precision}

The precision of the assay was determined by repeatability (intra-day) and intermediate precision (inter-day). Repeatability was evaluated by assaying samples, at same concentration and during the same day. The intermediate precision was studied by comparing the assays on different days $(3 \mathrm{~d})$. Five sample solutions were prepared and assayed. The \%R.S.D. value was lower than $2 \%$, assure the precision of the method and the results are shown in Table 2.

\section{Accuracy}

To check the degree of accuracy of the method, recovery studies were performed in triplicate by standard addition method at $50 \%, 100 \%$

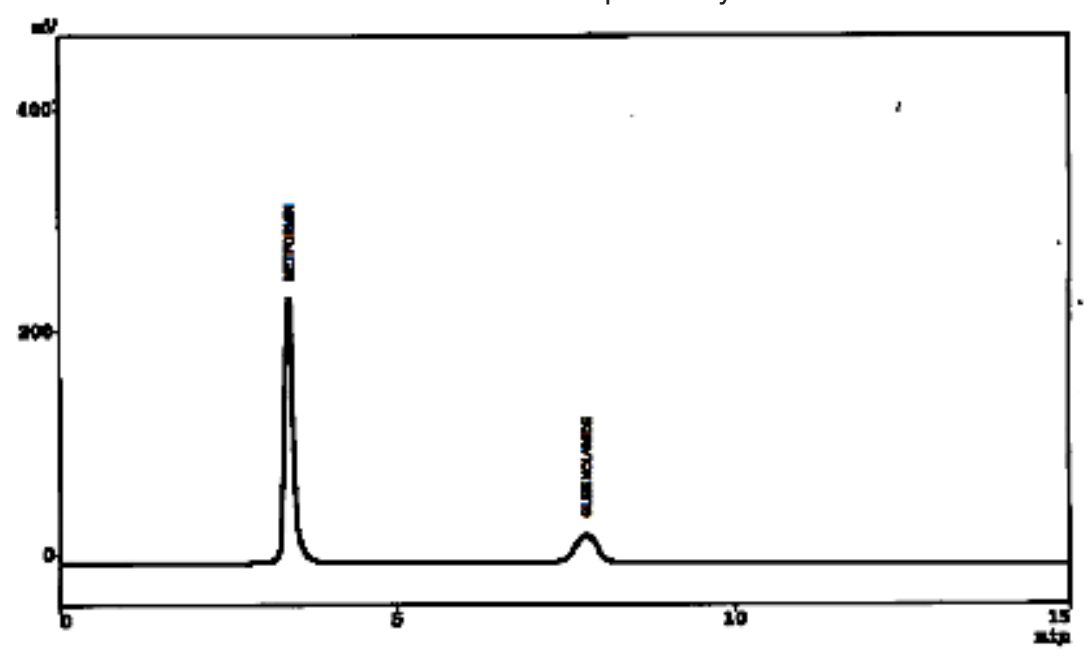

Fig.9: Chromatogram of $40 \mu \mathrm{g} / \mathrm{mL}$ MET (tR $=3.415)$ and $20 \mu \mathrm{g} / \mathrm{mL}^{-1} \mathrm{GLB}(\mathrm{tR}=7.792$ ) in pharmaceutical formulations 
and $150 \%$ of nominal analytical concentration (40 $\mu \mathrm{g} / \mathrm{mL}$ MET and $20 \mu \mathrm{g} / \mathrm{mL}$ GLB) were prepared and analyzed.. Known amounts of standard MET and BLG were added to pre-analyzed samples and were subjected to the proposed HPLC method. Results of recovery studies are shown in Table 2.

\section{Robustness}

Robustness for HPLC method was determined by analysis of samples under deliberately changed chromatographic conditions. The flow rate of the mobile phase was changed from $1 \mathrm{ml} / \mathrm{min}$ to $0.9 \mathrm{ml} / \mathrm{min}$ and $1.1 \mathrm{ml} / \mathrm{min}$ while the ratio of the mobile phase was changed by $\pm 2 \%$. The effect on retention time and peak parameter were studied.

\section{Detection and quantitation limits}

In accordance with the recommendations of $\mathrm{ICH}^{23}$, the limit of detection, LOD $=3.3$ "/S, where "is the standard of $y$-intercept and $S$ is the sensitivity, namely the slope of the calibration graph. The limit of quantitation, LOQ, is defined as 10 "/S. In the first derivative spectrophotometric method the LOD and $\mathrm{LOQ}$ were found to be $0.21 \mu \mathrm{g} / \mathrm{ml}$ and $0.64 \mu \mathrm{g} / \mathrm{ml}$ for MET and $0.29 \mu \mathrm{g} / \mathrm{ml}$ and $0.85 \mu \mathrm{g} / \mathrm{ml}$ for GLB, the scand derivative spectrophotometric method were found to be $0.46 \mu \mathrm{g} / \mathrm{ml}$ and $1.41 \mu \mathrm{g} / \mathrm{ml}$ for MET and $0.30 \mu \mathrm{g} / \mathrm{ml}$ and $0.91 \mu \mathrm{g} / \mathrm{ml}$ for GLB, respectively. In the HPLC method the LOD and LOQ were found to be $0.64 \mu \mathrm{g} / \mathrm{ml}$ and $1.91 \mu \mathrm{g} / \mathrm{ml}$ for MET and $0.02 \mu \mathrm{g} /$ $\mathrm{ml}$ and $0.07 \mu \mathrm{g} / \mathrm{ml}$ for GLB, respectively, Table 1. Obviously, the LOD and LOQ values are lower for the spectrophotometric methods due to the higher sensitivity of this technique.

\section{Assay of pharmaceutical preparations}

Due to the unavailability of the commercial tablets in the Saudi Arabia market, laboratory-made tablets were prepared and analyzed by the proposed first and second derivative spectrophotometric methods. No interference from commonly encountered tablet excipients such as talc, starch, lactose and magnesium stearate was observed in the analyses. The results, shown in Table 3, agree with nominal content showing reasonable precision and accuracy. This is evident from the low RSD (\%) and $\operatorname{Er}(\%)$ values. For each component, the results obtained by the proposed methods were statistically compared using the single factor analysis of variance (One-way ANOVA) test. The calculated t- test $f-$ test didn't exceed the critical value for any of the two drugs, indicating that there is no significant difference between the proposed methods ${ }^{24}$.

\section{Degradation behavior}

The results of the stress studies indicated the specificity of the method that has been developed. GLB was degraded only in $3 \% \mathrm{H}_{2} \mathrm{O}_{2}$ and in temperature stress conditions whereas MET was degraded in all conditions. The degraded products appeared at retention time (RTs) 2.18 and 2.48 in $0.1 \mathrm{M} \mathrm{HCl}, 2.16$ and 2.48 in $0.1 \mathrm{M} \mathrm{NaOH}$, 2.57 and 5.17 in $3 \% \mathrm{H}_{2} \mathrm{O}_{2}$ and 2.15, 2.45 and 5.08 in temperature degradation studies. The result of forced degradation studies are given in Table.4.

\section{CONCLUSION}

The ${ }^{1} \mathrm{D},{ }^{2} \mathrm{D}$ and HPLC methods enable the simultaneous determination of amlodipine and atorvastatin in their binary mixture with good accuracy and precision, either in laboratory prepared samples or in combined dosage form. HPLC method has the advantage of being more sensitive but the spectrophotometric ones are simpler and less expensive but all of the proposed methods are rapid and selective. The good recoveries obtained in all cases as well as the reliable agreement with the reported method proved that, the proposed methods could be applied efficiently for simultaneous determination of MET and GLB with quite satisfactory precision and could be easily used in quality control laboratory for their analysis. The proposed HPLC method is very comparable to the reported HPLC one regarding retention times and limit of quantitation of both drugs. In addition to that, the C18 column used in the proposed HPLC method is more preferred than that used in the reported HPLC method due its availability and lower cost.

\section{ACKNOWLEDGEMENTS}

This work has been supported by Deanship of Sicentifiv Research of Najran University. Project number: NU/MID/13/13. 


\section{REFERENCES}

1. British Pharmacopoeia, The British Pharmacopoeia Secretariat, London., 1993; p.1/305-1/ 415.

2. Prashanth, S.; Pradeep Kumar, Y.; Madhu, B.; Anil Kumar, A.; Int. J. Pharm. Bio. Sci. 2011, 1, 478-485.

3. Venkata Rayanm, I.; Lakshman Rao, A.; Ramana, M. V.; Int. J. Res. Pharm. Biomed. Sci, 2011, 2, 856-872.

4. Bandarkar, F. S.; Khattab, I. S.; J. Liquid. J. Chromatogr. Related.Technol, 2010, 33,1814-1830.

5. Deeb, S. E.; Pren, P.; Watzig, H.; J. Pharm. Biomed. Anal.; 2007, 44, 85-95.

6. Cicy, E.; Prasanth, V. G.; Amita, R.; Int. J. Chem. Tech. Res.; 2007, 4, 356-360.

7. Indian Pharmacopoeia: Government of India Ministry of Health and Family Welfare, Indian Pharmacopoeia Commission: Ghaziabad, 2007,p. 1165, 1358.

8. Brunton, L. L.; Lazo, J. S.; Parker, K. L.; Goodman and Gillman's The Pharmacological Basis of Therapeutics, 15th ed, McGraw-Hill Medical Publishing division, 2006, p. 1634

9. Kanij, F.; Zakiur, Md. R.; Tasnuva, H.; Abdul, Md. K. A.; Selim, Md. R.; Dhaka. Univ. J .Pharm. Sci, 2010, 9, 83-89.

10. Kar, M.; Choudhury, P. K.; Indian. J. Pharm. Sci, 2009, 71, 318-319.

11. Porta, V.; Schramm, S. G.; Kano, E. K.; Koono, E. E.; J. Pharm. Biomed. Anal, 2008, 46, 143147.
12. Umapathi, P.; Ayyappan, J.; Darlin Quine, S. Trop. J. Pharm. Res.; 2012, 11, 107-116.

13. Mubeen, G.; Noor, K.; Indian. J. Pharm. Sci.; 2009, 71,100-102.

14. Patil, S. S.; Bonde, C. G.; Int. J. Chem. Tech. Res.; 2009, 1, 905-909.

15. Khanolkar, D. H.; Shinde, V. M.; Indian Drugs, 1999, 36, 739-742.

16. Mistri, H. N.; Jangid, A. G.; Shrivastav, P. S.; J. Pharm. Biomed. Anal, 2007, 45, 97-106.

17. Chaturvedi, P. K.; Sharma, R.; Acta Chromatogr, 2008, 20, 451-461.

18. Aburuz, S.; Millership, J.; McEInay, J.; J. Chromatogr. B. Analyt .Technol. Biomed Life. Sci, 2005, 817,277-286.

19. De, A. K.; Dey, A. K.; Biswas, A.; IJSIT2, 2012, 1,98-105.

20. Sohrabi, M. R.; Kamali, N.; Khakpour, M,; Anal. Sic, 2011, 27, 1037-1041.

21. Georgita, C.; Albu, F.; David, V.; Medevedovici, A.; J. Chromatogr. B, 2007, 54, 211-218.

22. Lia, E. P.; Feng, S. Y.; J. Chromatogr. B, 2006, 843, 94-99.

23. International Conference on Harmonization, ICH Harmonized Tripartite Guidelines (Nov 2005), Validation of Analytical Procedures, Text and Methodology Q2 (R1). ICH, Geneva, 2005.

24. Miller, J. N.; Miller, J. C.; Statistics and Chemometrics for Analytical Chemistry, 5th edition. Pearson Education Limited, Harlow, UK, 2005 p. 39-73, 107-149. 